\title{
PML/RARa Interferes with NRF2 Transcriptional Activity Increasing the Sensitivity to Ascorbate of Acute Promyelocytic Leukemia Cells
}

\author{
Cristina Banella ${ }^{1,2}$, Gianfranco Catalano ${ }^{1,2}$, Serena Travaglini ${ }^{1}{ }^{\oplus}$, Mariadomenica Divona $^{3}$, \\ Silvia Masciarelli ${ }^{4,5,6}$, Gisella Guerrera ${ }^{7}$, Francesco Fazi ${ }^{6} \mathbb{C}$, Francesco Lo-Coco ${ }^{1,2}$, \\ Maria Teresa Voso ${ }^{1,2} \mathbb{D}$ and Nelida Ines Noguera ${ }^{1,2, * \mathbb{D}}$ \\ 1 Department of Biomedicine and Prevention, Tor Vergata University of Rome, 00133 Rome, Italy; \\ cristina.banella@gmail.com (C.B.); gianfranco.catalano@uniroma2.it (G.C.); serenatravaglini@live.it (S.T.); \\ francesco.lo.coco@uniroma2.it (F.L.-C.); Voso@med.uniroma2.it (M.T.V.) \\ 2 Neuro-Oncohematology Unit, Fondazione Santa Lucia, Istituto di Ricovero e Cura a Carattere \\ Scientifico (I.R.C.C.S.), 00143 Rome, Italy \\ 3 Oncologia Medica, Policlinico Universitario Tor Vergata, 00133 Rome, Italy; \\ mariadomenica.divona@ptvonline.it \\ 4 Istituto di Istologia ed Embriologia, Universita Cattolica del Sacro Cuore, 00168 Rome, Italy; \\ silvia.masciarelli@uniroma1.it \\ 5 Fondazione Policlinico Universitario A. Gemelli, I.R.C.C.S., 00168 Rome, Italy \\ 6 Department of Anatomical, Histological, Forensic \& Orthopedic Sciences, Sapienza University of Rome, \\ Laboratory Affiliated to Istituto Pasteur Italia-Fondazione Cenci Bolognetti, 00161 Rome, Italy; \\ francesco.fazi@uniroma1.it \\ 7 Neuroimmunology and Flow Cytometry Units, Fondazione Santa Lucia I.R.C.C.S., 00143 Rome, Italy; \\ g.guerrera@hsantalucia.it \\ * Correspondence: n.noguera@hsantalucia.it; Tel.: +39-065-0170-3214; Fax: +39-065-0170-3318
}

Received: 20 December 2019; Accepted: 27 December 2019; Published: 30 December 2019

\begin{abstract}
NRF2 (NF-E2 p45-related factor 2) orchestrates cellular adaptive responses to stress. Its quantity and subcellular location is controlled through a complex network and its activity increases during redox perturbation, inflammation, growth factor stimulation, and energy fluxes. Even before all-trans retinoic acid (ATRA) treatment era it was a common experience that acute promyelocytic leukemia (APL) cells are highly sensitive to first line chemotherapy. Since we demonstrated how high doses of ascorbate (ASC) preferentially kill leukemic blast cells from APL patients, we aimed to define the underlying mechanism and found that promyelocytic leukemia/retinoic acid receptor $\alpha$ (PML/RARa) inhibits NRF2 function, impedes its transfer to the nucleus and enhances its degradation in the cytoplasm. Such loss of NRF2 function alters cell metabolism, demarcating APL tissue from both normal promyelocytes and other acute myeloide leukemia (AML) blast cells. Resistance to ATRA/arsenic trioxide (ATO) treatment is rare but grave and the metabolically-oriented treatment with high doses of ASC, which is highly effective on APL cells and harmless on normal hematopoietic stem cells (HSCs), could be of use in preventing clonal evolution and in rescuing APL-resistant patients.
\end{abstract}

Keywords: acute promyelocytic leukemia; PML/RARa; NRF2; HMOX1; ascorbate; ROS

\section{Introduction}

Acute myeloid leukemias (AMLs) are clonal disorders of the hematopoietic system characterized by the rapid growth of abnormal precursors cells that interfere with normal hemopoiesis. Acute promyelocytic leukemia (APL) is a subtype of AML characterized by a reciprocal and balanced 
translocation involving retinoic acid receptor $\alpha(\mathrm{RARa})$ on chromosome 17 and promyelocytic leukemia (PML) on chromosome 15 which generates the oncogenic PML-RAR $\alpha$ fusion protein. Central in the pathogenesis of APL, PML/RARa impairs formation of functional PML nuclear bodies, and acts as a transcriptional repressor antagonizing myeloid differentiation, altering DNA repair and promoting the self-renewal capacity of APL-initiating cells [1-4].

Cap'n'Collar basic leucine zipper transcription factor NF-E2 p45-related factor 2 (NRF2) plays a crucial role in orchestrating adaptive cell response to stress. NRF2 binds to antioxidant response elements (AREs) in the promoter region of genes involved in redox regulation, proteostasis, DNA repair, apoptosis, nutrient and xenobiotic metabolism [5-11].

Ascorbic acid, commonly known as an antioxidant when used in low doses, is an essential nutrient that acts as a coenzyme in several enzymatic reactions. In the early 1970s, Pauling and Cameron reported on the possible benefit of high-dose intravenous and oral ASC for cancer patients [12,13]. A recent study showed that high-dose vitamin $C$ selectively kills colon cancer cells carrying KRAS (KRAS proto-oncogene, GTPase) or BRAF (B-Raf proto-oncogene, serine/threonine kinase) mutations [14]. A series of in vitro and in vivo studies revived the interest of high doses of ascorbate (ASC) as an anticancer agent. In particular, studies from our group and others revealed that, when administered in pharmacologic doses corresponding to the millimolar (mM) range, ASC behaves as a powerful pro-oxidant, generating hydrogen peroxide-dependent cytotoxicity towards a variety of cancer cells in vitro without adversely affecting normal cells [15-18]. A different view of the potential action of vitamin $C$ in cancer came from the discovery of its importance for the activation of the ten-eleven translocation (TET) and Jumonji dioxygenases that are involved in active demethylation of DNA and histones, respectively $[19,20]$.

NRF2 is tightly regulated to assure cell homeostasis: In normal conditions low levels of NRF2 are maintained by the association with Kelch-like ECH-associated protein 1 (Keap1) in a complex with E3 ubiquitin ligase Cullin 3-Ring-box protein 1 (CUL3-RBX1) and degradation by proteasome [21,22]. Oxidants and electrophilic molecules induce modifications in Keap1 that prevents the ubiquitination of NRF2 [23]. NRF2 then translocates to the nucleus, heterodimerizes with small musculoaponeurotic fibrosarcoma (sMAF) proteins and binds to antioxidant response elements (AREs) to promote the expression of more than 200 genes [24-26]. Finally, it entangles with a Skp1-Cullin 1 (CUL1) F-box-containing complex that targets NRF2 for proteasomal degradation or with RNF4 E3 ubiquitin ligase leading to degradation in promyelocytic-nuclear bodies (PML-NB) domains within the nucleus [27-30]. Hematopoietic cells appear to be particularly vulnerable to the accumulation of reactive oxygen species (ROS), since deficiencies in ROS scavenger proteins result in severe anemia and/or carcinogenesis [31,32]. Thus the tight regulation of NRF2 is important to assure cell homeostasis. Stem cells have a low energetic profile with scarce ROS production. In the hemopoietic compartment, the loss of NRF2 results in defective differentiation and decreased survival as well as defective engraftment after hematopoietic stem cell (HSC) transplantation [33]. However, there is no increased ROS production but rather a sensitization to ROS hyper-production induced by oxidative stress [33]. Since we demonstrated that high doses of ascorbic acid (ASC) preferentially kill leukemic blasts from APL patients while sparing normal HSCs $[17,18]$ we aimed to define the effect of PML/RARa on NRF2 function in hematopoietic cells.

\section{Material and Methods}

\subsection{Primary Patient Samples}

Bone marrow (BM) mononuclear cells (MNC) were collected from patients with newly diagnosed AML and APL. APL diagnosis was confirmed in all cases through detection of the PML/RARa fusion gene by RT-PCR. BM-infiltration by leukemic blasts was $>70 \%$ in all patients included in the study. BM-MNC isolated from healthy individuals were used as control. Written informed consent was obtained from all patients according to institutional guidelines and the declaration of Helsinki. 
The study had been approved by the independent ethical commitment of Foundation PTV Policlinico Tor Vergata—Experimental Register R.S. 208/18 on 23th January 2019.

Total RNA was extracted from Ficoll-Hypaque-isolated mononuclear cells using the method of Chomczynsky and Sacchi. RNA was reverse-transcribed using random hexamer primers.

\subsection{Cell Cultures}

NB4, an APL-derived cell line, carrying the $t(15 ; 17)$ translocation was purchased from DSMZ (Braunschweig, Germany); U937, an histiocytic lymphoma-derived cell line; Mock and PR9 (a zinc-inducible PML/RARa model constructed from the U937 cell line) [34]; and HL-60, an AML FAB M2-derived cell line and Oci-AML2, an AML-M4-derived cell line carrying the DNMT3A R635W mutation (kindly provided by Emanuela Colombo, European Institute of Oncology, Milan, Italy) were grown at $37^{\circ} \mathrm{C}$ in a humidified atmosphere of $5 \% \mathrm{CO} 2$ in air in RPMI (Roswell Park Memorial Institute Medium) (GIBCO-BRL, Grand Island, NY, USA) supplemented with $10 \%$ fetal bovine serum (FBS) (GIBCO-BRL), $20 \mathrm{mM}$ Hepes, $100 \mu \mathrm{g} / \mathrm{mL}$ penicillin and $100 \mu \mathrm{g} / \mathrm{mL}$ streptomycin (GIBCO-BRL).

The HEK293T, a human embryonal kidney cell line (kindly provided by Corinna Giorgi, European Brian Research Institute, Rome) was cultured as a monolayer in Dulbecco's modified eagle medium containing $10 \%$ fetal bovine serum, $100 \mathrm{mg} / \mathrm{mL}$ penicillin and $100 \mathrm{mg} / \mathrm{mL}$ streptomycin.

Cells were tested regularly for mycoplasma contamination using a PCR kit (N-Garde EMK090020, Euroclone, Milan, Italy).

\subsection{Immunofluorescence Assays}

Immunofluorescence was used to evaluate the localization of NRF2 in the presence of PML/RARa. U937-PR9 and Mock control cells were prepared using a cytocentrifuge. Assays were performed as previously described [35]. Briefly, cells fixed with $4 \%$ paraformaldehyde (PFA) were permeabilized in PBS containing $0.1 \%$ Nonidet P-40 and blocked in 3\% bovine serum albumin (BSA) (Sigma-Aldrich, St. Louis, MO, USA). Slides were incubated overnight with the primary antibody anti-PML, kindly provided by Brunangelo Falini; and anti-NRF2 (Ab Cam, Cambridge, UK); and following two PBS washes and incubated for $2 \mathrm{~h}$ with the secondary antibodies: Alexa Fluor 555-labeled goat anti-mouse and Alexa Fluor 488-labeled goat anti-rabbit (diluted 1:400 with PBS+BSA 3\%) (Invitrogen, Carlsbad, CA, USA).

The nuclei were stained with $1 \mu \mathrm{g} / \mathrm{mL}$ DAPI (4',6-diamidino-2-phenylindole) (Sigma-Aldrich, St. Louis, MO, USA) for $5 \mathrm{~min}$ in PBS. Finally, cells were rinsed and mounted in Fluoromount (Sigma-Aldrich). Images were acquired using a Zeiss LSM 700 (Carl Zeiss Microscopy, Jena, Germany) confocal laser scanning microscope.

\subsection{Quantitation of ROS}

To evaluate ROS levels cells were incubated for $24 \mathrm{~h}$ with $\mathrm{Zn}$. The Abcam's ROS assay kit "ab113851" (Abcam, Cambridge, UK) uses the cell permeant reagent 2', $7^{\prime}$-dichlorofluorescein diacetate (DCFDA), a fluorogenic dye that measures hydroxyl, peroxyl and other ROS activity within the cell. After diffusion into the cell DCFDA was deacetylated by cellular esterases to a non-fluorescent compound, which was later oxidized by ROS into $2^{\prime}, 7^{\prime}$-dichlorofluorescein (DCF). The cells were then analyzed using a Beckman Coulter CyAn ADP (Beckman Coulter, Chapel Hill, NC, USA).

\subsection{Transfection Experiments}

To evaluate the effect of PML/RARa on NRF2 half life, Hek293T cells were transfected with pSG5-PML/RARa or pSG5 constructs using jetPRIME ${ }^{\circledR}$ transfection reagent (Polyplus-transfection ${ }^{\circledR}$, Strasbourg, France). The cells were treated with $\mathrm{ZnSO}_{4} 100 \mu \mathrm{M}$ for two hours to induce NRF2 expression and then the stops were initiated over five hours. 
HL-60 cells were transfected with pSG5-PML/RARa or pSG5 constructs using Amaxa Cell Line Nucleofector Kit C (Lonza, Cologne GmbH, Germany). After 24 h the cells were treated with ZnSO4 $100 \mu \mathrm{M}$ for two hours to induce NRF2 expression and then with cycloheximide (CHX) (Sigma-Aldrich, St. Louis, MO, USA), $0.2 \mathrm{nM}$ for another four hours.

\subsection{Western Blot Analysis}

Western blot was used to evaluate the expression level of NRF2 and Keap1 [36]. Cell pellets were re-suspended in lysis buffer containing $10 \mathrm{mM}$ Tris- $\mathrm{HCl}(\mathrm{pH}$ 7.4), $5 \mathrm{mM}$ etilendiammonotetracetico (EDTA) (Sigma-Aldrich, St. Louis, MO, USA)., $150 \mathrm{mM} \mathrm{NaCl}, 1 \%$ Triton X-100, $250 \mu \mathrm{M}$ orthovanadate, $20 \mathrm{mM} \beta$-glycerophosphate and protease inhibitors (Sigma-Aldrich). Lysates were centrifuged at $10000 \mathrm{~g}$ for $15 \mathrm{~min}$ at $4{ }^{\circ} \mathrm{C}$ and supernatants were stored at $-80^{\circ} \mathrm{C}$. Twenty microgram aliquots of proteins were resuspended in a reducing Laemmli Buffer (with $\beta$-mercaptoethanol) and loaded onto a $10 \%$ polyacrylamide gel, then transferred to nitrocellulose membrane. After blocking with $5 \%$ milk (Fluka, Sigma-Aldrich, St. Louis, MO, USA), the membranes were incubated with specific antibodies, as listed in Supplementary Table S1. IgG-Horseradish peroxidase-conjugated preparations were used as secondary antibodies and the enhanced chemiluminescence (ECL) procedure was employed for development (ECL kits, Amersham, Buckinghamshire, UK). Nuclear and cytoplasm fraction were obtain using NE-PER nuclear and cytoplasmic extraction reagents from Thermo Scientific (Rockford, IL, USA) according to instructions [36].

The autoradiograms obtained were scanned and exported for densitometry analysis. Protein signal intensities were measured by using ImageJ-win64 software.

\subsection{Quantitative Real-Time Expression Analysis}

Q-RT-PCR was used to evaluate the expression level of NRF2 and its target genes HMOX1, NQO-1 and $A K R 1 C 1$. Reverse transcription was performed using $1 \mu \mathrm{g}$ total RNA and a standardized protocol (Applied Biosystems, Foster City, CA, USA). The primers were obtained from Sigma (Saint Louis, MO, USA) (Table S1). The reaction mixture of $20 \mu \mathrm{L}$ contained $1 \times$ Syber Green Supermix (Biorad, Benicia, CA, USA), $300 \mathrm{nM}$ of each primer. All expression levels (gene of interest and normalization control) in quantitative RT-polymerase chain reactions (RQ-PCR) were obtained by the use of standard curves. Primers used are shown in Supplementary Table S2.

\subsection{Survival Assay}

To study if PML/RARa affected the cell sensitivity to ASC survival assays were performed. Cells were plated in 96-well plates at 7000 cells/well, exposed to vehicle, $1 \mathrm{mM}$ or $3 \mathrm{mM} \mathrm{ASC}$, and cultured for three days. Cell survival was evaluated by the CellTiter $96{ }^{\circledR}$ AQueous One Solution Cell Proliferation Assay Kit (Promega, Boston, MA, USA) or ATPlite Luminescence Assay System (Perkin Elmer $\mathrm{GmbH}$, Überlingen, Germany) according to the manufacturer's instructions.

\subsection{Immunoprecipitation}

To analyze if physical interaction between PML/RARa and NRF2 existed, total extracts and nuclear and cytoplasm fractions were used for co-immunoprecipitation assays. Briefly, $1 \mathrm{mg}$ of extract was incubated overnight at $4{ }^{\circ} \mathrm{C}$ with $2 \mu$ g of antibody (anti-NRF2, anti-PML and anti-RARa), and subsequently for $45 \mathrm{~min}$ at $4{ }^{\circ} \mathrm{C}$ with Dynabeads Protein $\mathrm{G}$ (Invitrogen, Dynal AS, Oslo, Norway). Samples were then blotted with anti-NRF2 or anti-RARa antibodies (Supplementary Table S1).

\subsection{CHIP Assay}

To analyze if PML/RARa affected the binding of NRF2 to its target genes, experiments on chromatin immunoprecipitation (ChIP) assays were performed. The genomic regulatory regions for HMOX1 gene are located upstream the first exons of the HMOX1 locus (10 kbs, position: 35371096 to 35381173 ). 
Reichard et al. demonstrated that NRF2 binds to two distal ARE enhancer sites far upstream of the HMOX1 transcription start site (TSS) [37,38]. For this reason, quantitative real-time PCR (qPCR) was performed targeting the distal antioxidant response element (ARE) of the HMOX1 gene. ChIP assays were performed as previously described [39]. Briefly, DNA was double-crosslinked to proteins with $1 \%$ formaldehyde (Sigma, St Louis, MI, USA) and after incubation for $20 \mathrm{~min}$ at room temperture, glycine was added to a final concentration of $0.125 \mathrm{M}$, for five minutes. After washing twice in $1 \times$ PBS, cell lysis buffer (10 mM Tris $\mathrm{pH} 8.0,100 \mathrm{mM} \mathrm{NaCl}$ and $0.2 \%$ NP40) was added to the samples, and cells were incubated on ice for $30 \mathrm{~min}$. Nuclei were pelleted at $1500 \mathrm{rpm}$ at $4{ }^{\circ} \mathrm{C}$, and after addition of the nuclear lysis buffer (50 mM Tris pH 8.1, $10 \mathrm{mM}$ EDTA and $1 \%$ sodium dodecyl sulfate (SDS), were incubated on ice for $30 \mathrm{~min}$. Chromatin fragments of around 200-300 bp were obtained by sonication, using a Branson Sonifier 450 Analog Cell Disruptor. For each immunoprecipitation, $3 \mathrm{mg}$ of antibodies (Supplementary Table S1) were conjugated to magnetic beads (G-protein magnetic beads, Invitrogen, Dynal, Oslo, Norway). After extensive washing, bound DNA fragments were eluted and analyzed by quantitative PCR using the SYBR Green Master Mix (Biorad, Benicia, CA, USA). ChIP signals were normalized against the input and expressed as relative enrichment of the material, precipitated by the NRF2 antibody binding to the HMOX1. Relative quantification using the comparative Ct method (percent input method, signals obtained from the ChiP divided by signal from an input sample adjusted to $100 \%$ ). In addition, an unrelated sequence in the GAPDH gene was used as a negative control (primers listed in Supplementary Table S2).

\subsection{Statistical Analysis}

All statistical analyses were conducted using the GraphPad Prism5 software [40]. The unpaired $t$-test compares the means of two unmatched groups, assuming that the values follow a Gaussian distribution; when the distribution was not normal we used the Mann-Whitney test, and all tests were done on two sides.

\section{Results}

\subsection{NRF2 Protein Level, but Not mRNA, Is Lower in APL Than in Other AML}

Since in a previous work we demonstrated a peculiar sensitivity of APL blast cells to pharmacologic doses of ascorbate [17] we decided to examine NRF2 expression in these cells because of the important role of NRF2 in orchestrating cellular response to stress. Using western blot, we found that APL blasts express NRF2 protein at a significantly lower level $(0.6 \pm 0.8, n=8)$ than other AMLs samples $(1.2 \pm 0.4$, $n=7)(p=0.02)$ (Figure 1a). On the other hand, NRF2 mRNA expression, assessed by Q-RT-PCR, was significantly higher in APL $(n=13 ; 0.12 \pm 0.1)$ and in AML $(n=12 ; 0.24 \pm 0.3)$ as compared to normal bone marrow $(\mathrm{NBM})(n=5 ; 0.03 \pm 0.01$, APL vs. normal bone marrow (NBM), $p=0.04$, AML vs. NBM, $p=0.004$ ) (Figure $1 \mathrm{~b}$ ), indicating post-transcriptional regulation of NRF2 expression. To note that Keap1 protein, the main regulator of NRF2 degradation, is evenly expressed in APL $n=8(0.91 \pm 0.3)$ and AML $n=7(0.99 \pm 0.2)$ patients' samples (Figure 1c), hence a different player is involved.

\subsection{NRF2 Transcriptional Activity Is Inhibited in APL Cells}

To ascertain NRF2 transcriptional activity in APL cells we measured mRNA expression of three NRF2 target genes in cells isolated from the bone marrow of 13 APL patients, 12 AML patients and five healthy donors (NBM) using quantitative RT-PCR. We tested HMOX1, NQO-1 and AKR1C1: In APLs mean values were: $1.7 \pm 1.8 ; 10.5 \pm 9.8$ and $0.25 \pm 0.37$; in AMLs: $30.6 \pm 30.2 ; 44 \pm 46$ and $0.9 \pm 1.8$, and in NBMs: $1.6 \pm 1.8 ; 1.1 \pm 0.5$ and $1.0 \pm 0.3$ respectively. AML samples were characterized by heterogeneous expressions levels, average expression was significantly higher than that of APL samples ( $p=0.0007 ; p=0.0016$ and $p=0.005$ respectively) (Figure 2a) clearly showing inhibition of NRF2 transcriptional activity in APL cells. 
a
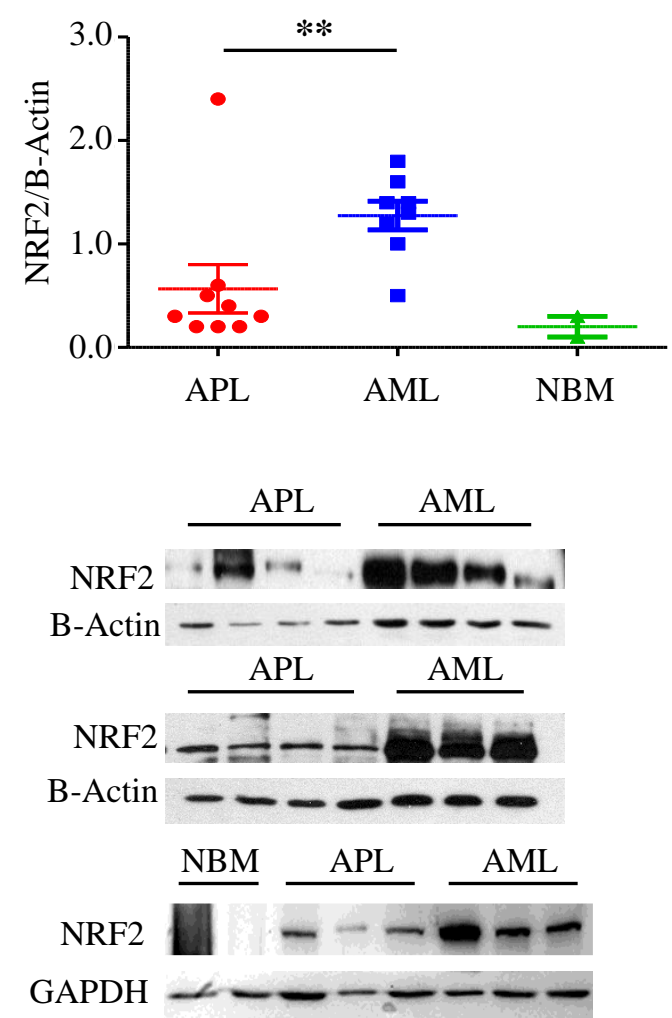

b

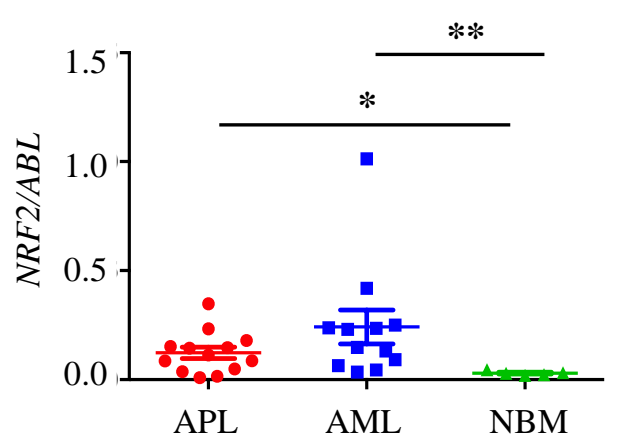

C
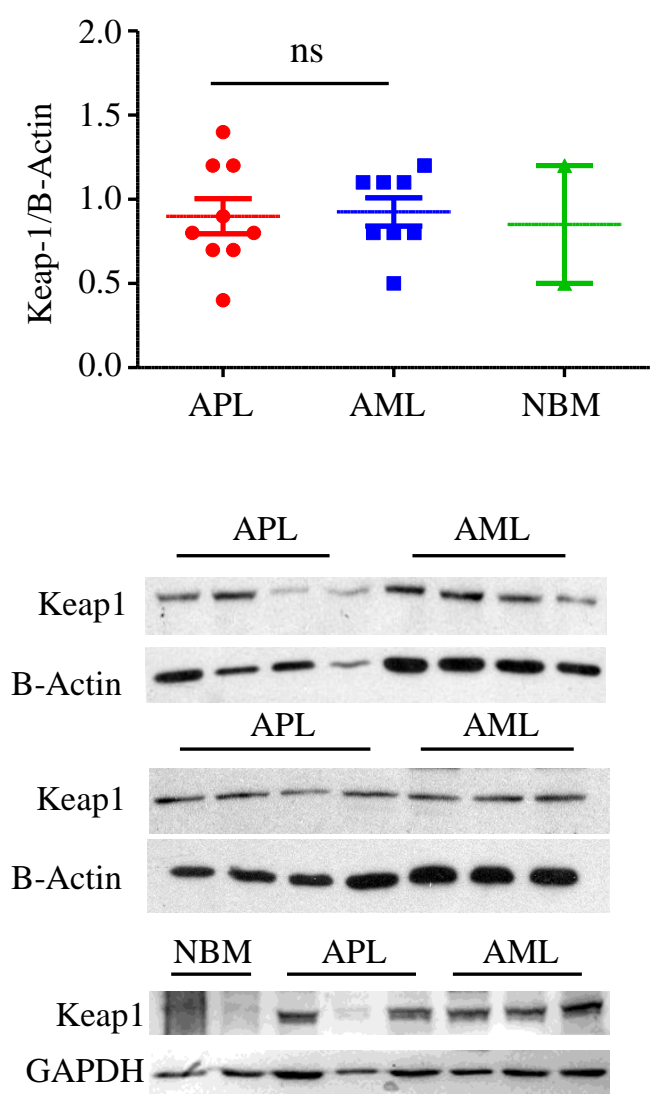

Figure 1. NF-E2 p45-related factor 2 (NRF2) protein level is lower in acute promyelocytic leukemia (APL) than in other acute myeloide leukemia (AML). (a) Western blot analysis of NRF2 in two samples from normal bone marrow (NBM), nine samples from APL patients and eight samples from AML patients. (b) Q-RT-PCR on NRF2 mRNA in 13 APL, 12 AML and five normal bone marrow (NBM) samples. (c) Western blot analysis of Keap1 in two samples from NBM, nine samples from APL patients and eight samples from AML patients. ns: non significative ${ }^{*}: p \leq 0.05 ;{ }^{* *}: p \leq 0.005$ by Mann Withney test, not normal distribution. 

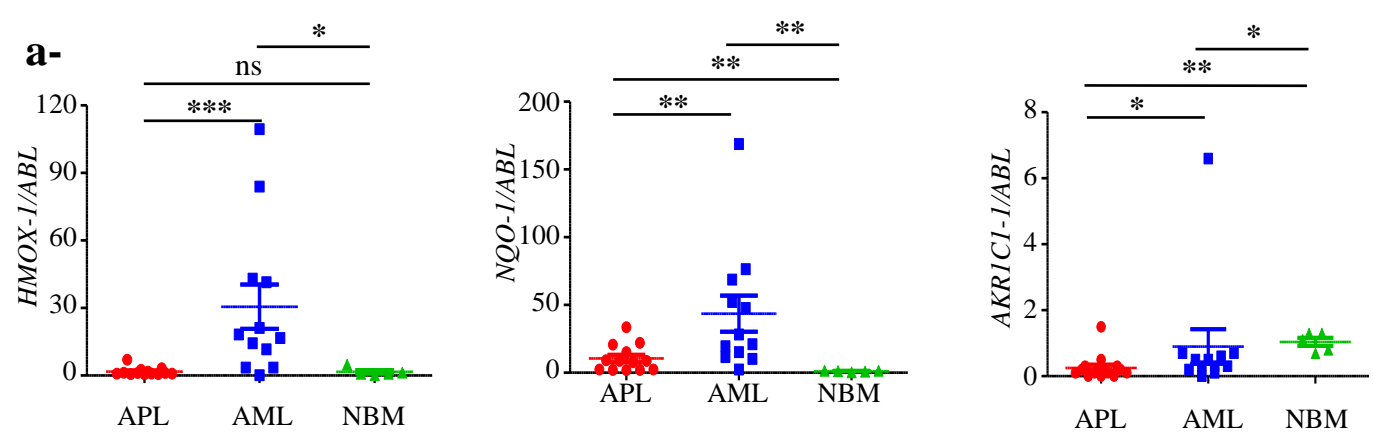

b-

c-
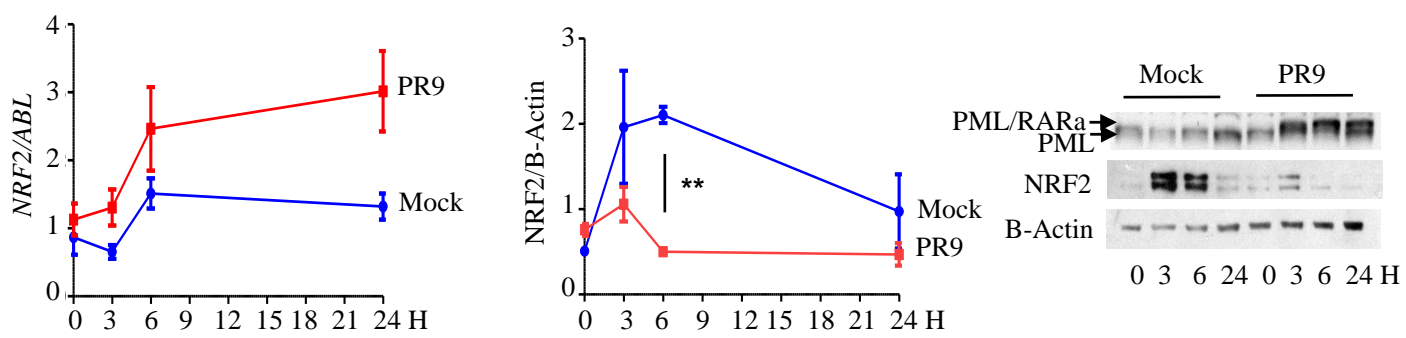

d-

e-
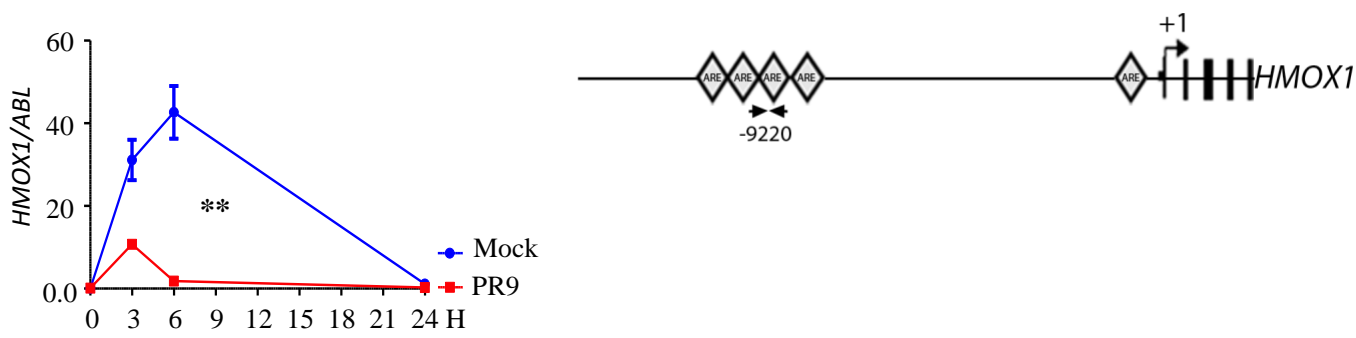

f-
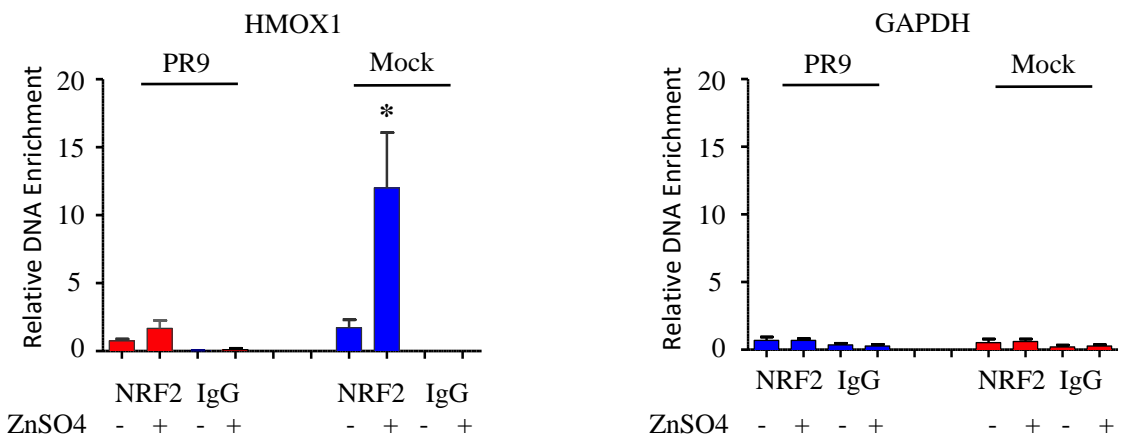

Figure 2. Promyelocytic leukemia/retinoic acid receptor $\alpha$ (PML/RARa) inhibits NF-E2 p45-related factor 2 (NRF2) transcriptional activity by preventing its binding to antioxidant response elements (ARE) motifs. (a) mRNA expression of NRF2 target genes: HMOX1, NQO-1 and AKR1C-1 in 13 APL, 12 AML and 5 normal bone marrow (NBM) samples. ${ }^{*} p \leq 0.05 ;{ }^{* *}: p \leq 0.01$; ${ }^{* *}: p \leq 0.001$ by the Mann-Whitney test, not normal distribution. (b) NRF2 mRNA expression induction in a $24 \mathrm{~h}$ time course after ZnSO4 addition is higher in PR9 than in Mock control cells. The experiments were performed in triplicate. (c) NRF2 protein level increases and persists higher in a $24 \mathrm{~h}$ time course after 
treatment with $\mathrm{ZnSO}_{4}$ in Mock control cells; conversely, in PR9 cells after a short lived augment, it abates due to the presence of PML/RARa. The experiments were done by triplicate. ${ }^{* *}: p \leq 0.005$ by unpaired $t$-test. (d) PML/RARa expression after treatment with $\mathrm{ZnSO}_{4}$ in PR9 cells inhibits the transcriptional activity of NRF2 as measured by HMOX1 expression. The experiments were done by triplicate. ${ }^{* *}: p \leq 0.005$ by unpaired $t$-test. (e) The squares indicate the position of putative ARE motifs relative to the HMOX1 transcription start site (TSS). The arrows indicate the position of primers used to analyze the putative ARE binding site in the HMOX1 gene. The experiment were done by triplicated. *: $p \leq 0.05$ by unpaired $t$-test. (f) PML/RARa decreases binding of NRF2 to the HMOX1 promoter region. The binding of NRF2 markers to DNA was measured by a quantitative ChIP assay in PR9 and Mock cells after treatment with $\mathrm{ZnSO}_{4}(100 \mu \mathrm{M})$. Data are shown as fold-enrichment of ChIP DNA versus input DNA. GAPDH was used as negative control. Data are representative of four independent experiments. $p=0.02$ by Mann-Whitney test. Not normal distribution.

3.3. PML/RARa Inhibits the Increase of NRF2 Protein and Interferes with NRF2 Transcriptional Activity by Preventing Its Binding to ARE Motifs

To study the effect of PML/RARa expression on NFR2 we used a myeloid-inducible system: PR9 cells (U937 cell line with a zinc inducible PML/RARa expression) and Mock control cells (U937 lacking PML/RARa sequence on the transfected construct). Since $\mathrm{ZnSO}_{4}$ induces NRF2 expression we felt it was a good system to analyze PML/RARa interference with NRF2 induction. After $100 \mu \mathrm{M}$ zinc sulphate $\left(\mathrm{ZnSO}_{4}\right)$ addition, in Mock cells NRF2 mRNA increases after six hours $(1.5 \pm 0.4)$ and slightly decreases in the following hours, whereas in PR9 cells the increase is higher in the first six hours $(2.46 \pm 1)$ and persistent up to $24 \mathrm{~h}$ (Figure $2 \mathrm{~b}$ ). Conversely NRF2 protein levels augment in Mock cells more than four folds in the first six hours $(2.1 \pm 0.1)$ and persists two folds higher after $24 \mathrm{~h}(1 \pm 0.8)$, whereas in PR9 cells, after a slight increase in the first three hours $(1 \pm 0.4)$, the protein abates to a level lower than normal $(0.5 \pm 0.1)$ (Mock vs. PR9 $p=0.008)$ up to $24 \mathrm{~h}$ (Figure $2 \mathrm{c}$ ), suggesting that PML/RARa doesn't interfere with NRF2 mRNA induction but with the protein stability. To further study if that down-modulation of NRF2 affects the expression of its target genes we measured in the same system the expressed levels of HMOX1, that normally exerts an important antioxidant effect in cancer cells. We could see that in PR9 cells after an initial induction at three hours, much lower than the control's (11 \pm 0.5 vs. $32 \pm 8)$, and transcriptional activity drops (PR9 cells + Zn $1.8 \pm 0.6$ vs. Mock + Zn $42.7 \pm 11$ at $6 \mathrm{~h}, p=0.003$ ) (Figure $2 \mathrm{~d}$ ). One should note that the kinetics of the NRF2 protein and the induced HMOX1 expression are identical and indicates that the lack of NRF2 function in the presence of PML/RARa stimulates its transcription from the homeostatic cellular apparatus to no avail, since there is no increase in NRF2 protein and function.

To ascertain the specificity of PML/RARa inhibition we performed a specific ChIP analysis on distal HMOX1 ARE motifs [29,30] (Figure 2e) using the inducible system PR9 and Mock control cells. After four hours of treatment with $\mathrm{ZnSO}_{4}$ the binding of NRF2 to HMOX1 gene is seven folds higher in Mock cells compared to PR9 cells ( $12 \pm 8$ vs. $1.7 \pm 1.1 ; p=0.02)$ (Figure 2f) demonstrating the specific inhibition of NRF2 physical binding to the target ARE sequence in the presence of PML/RARa.

3.4. PML/RARa Binds to NRF2, Impairs Its Nuclear Translocation, Promotes Its Cytoplasmic Degradation and Shortens Its Lifespan

Since the transcriptional function of NRF2 is nuclear we decided to look into the PML/RARa effect on the cellular localization of NRF2. By confocal microscopy we observed that, in untreated and un-induced PR9 cells, the NRF2 protein was localized mainly in the nucleus in PML-NBs. Eight hours after PML/RARa induction, in coincidence with PML NBs disruption, NRF2 protein was mainly confined to the cytoplasm (Figure 3a). We confirmed the subcellular localization of NRF2 protein by western blot analysis, separating nuclear and cytoplasmic cellular fractions. In Mock control cells we registered a 50\% enhancement of nuclear NRF2 $(p=0.01)$, conversely in PR9 cells PML/RARa expression caused a 26\% enhancement of cytoplasmic NRF2 $(p=0.009)$ (Figure 3b). 
a-
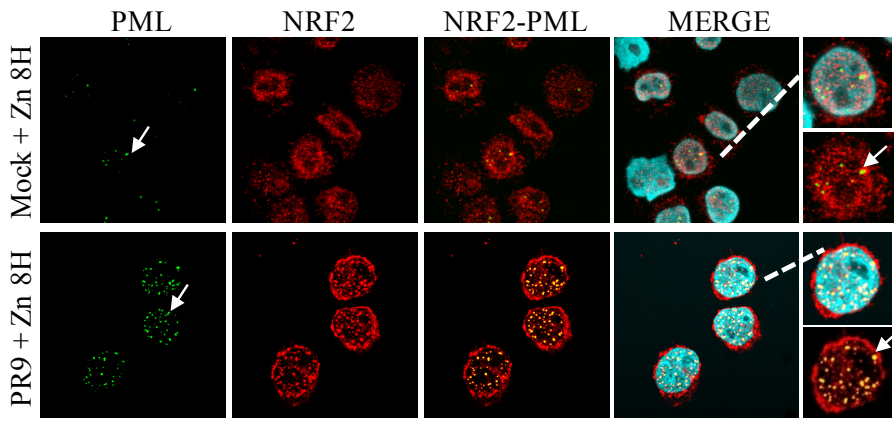

b-
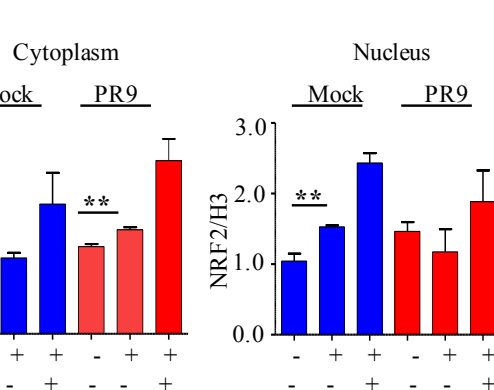

c-

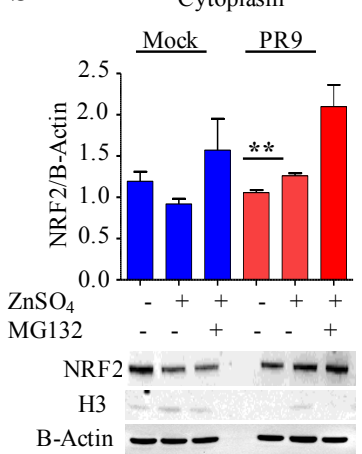

IP: PML and RARa WB: NRF2
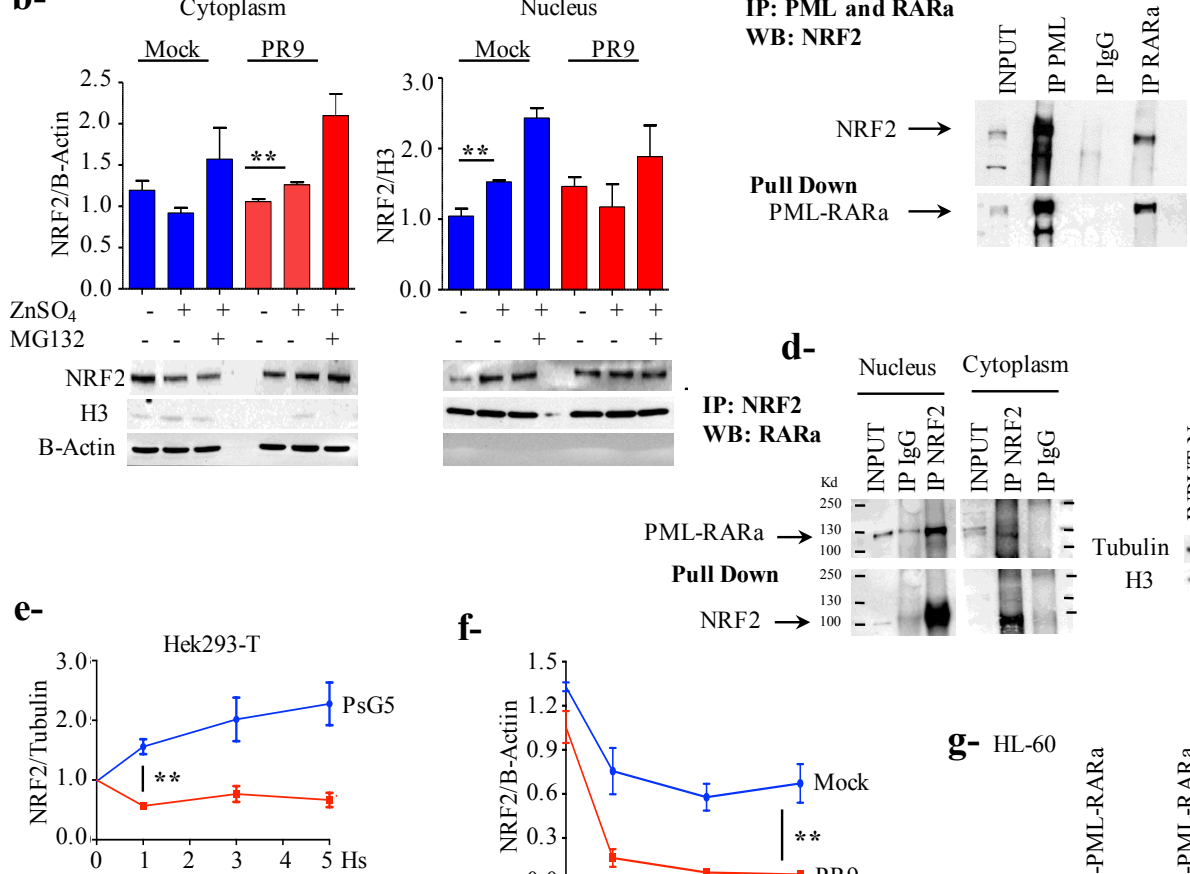

f-

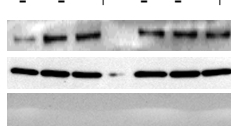

\section{d-}
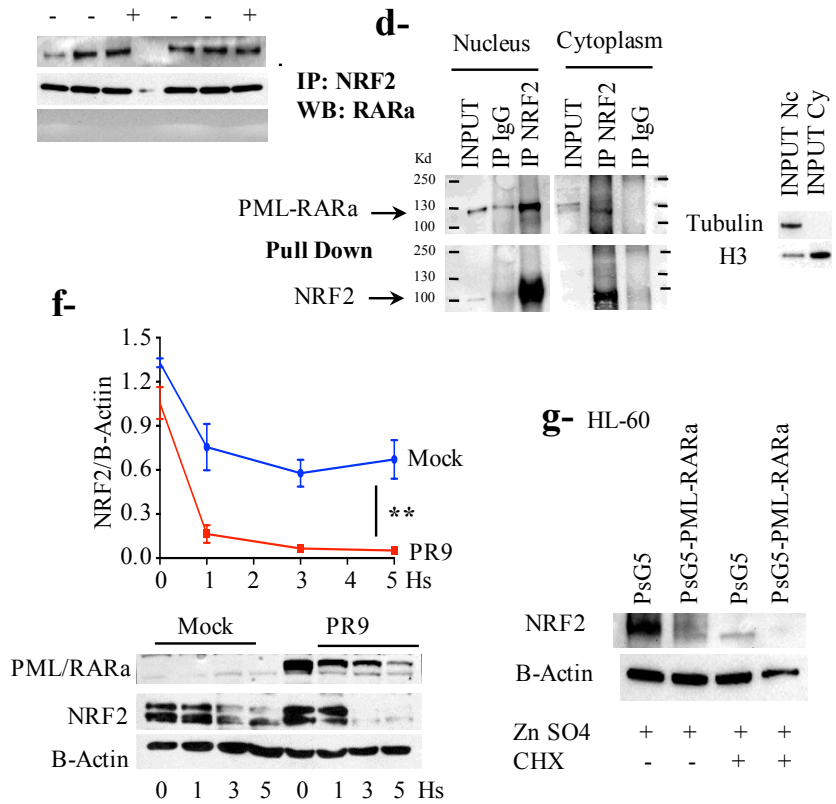

Figure 3. Promyelocytic leukemia/retinoic acid receptor $\alpha$ (PML/RARa) binds to NF-E2 p45-related factor 2 (NRF2), promotes its cytoplasmic degradation and shortens its lifespan. (a) At confocal microscopy NRF2 translocates to the cytoplasm eight hours following PML/RARa expression induction. The arrow indicates promyelocytic leukemia-nuclear bodies (PML-NBs). (b) Cytoplasmic translocation is confirmed by nuclear/cytoplasmic fractionation. (c) PR9 cells where treated with $\mathrm{ZnSO}_{4} 100 \mu \mathrm{M}$ for four hours, after that cross-immunoprecipitation experiments where done showing that PML/RARa interacts with NRF2. (d) Co-immunoprecipitation of NRF2 in the cytoplasm and nucleus using PR9 cells previously treated with $\mathrm{ZnSO}_{4}$ for four hours demonstrated an interaction between PML/RARa and NRF2 in both fractions. (e) Hek293T cells were transfected with pS5G or pS5G-PML/RARa, after $24 \mathrm{~h}$ where treated with $\mathrm{ZnSO}_{4} 100 \mu \mathrm{M}$ to evaluate the effect of PML/RARa on NRF2 induction. PML/RARa inhibit the expression of NRF2 (f) PR9 cells and the control Mock cells were treated with $\mathrm{ZnSO}_{4} 100$ $\mu \mathrm{M}$ for two hours and then with cycloheximide (CHX) $100 \mu \mathrm{g} / \mathrm{mL}$ for five hours. Time 0 refers to the moment in which cycloheximide was added, $+2 \mathrm{~h}$ after zinc induction. PML/RARa reduce significantly the half-life of NRF2. (g) HL60 cells were transfected with pS5G or pS5G-PML/RARa for $24 \mathrm{~h}$, then treated with ZnSO4 $100 \mu \mathrm{M}$ for two hours and then with CHX $100 \mu \mathrm{g} / \mathrm{mL}$ for four hours. PML/RARa reduce the half life of NRF2. This experiment was done twice. All the other experiments were done by triplicate. ${ }^{*}: p \leq 0.05 ;{ }^{* *}: p \leq 0.01$ by unpaired $t$-test. 
We performed co-immunoprecipitation experiments, demonstrating a physical interaction between the two proteins as part of the mechanism for the inhibition of NRF2 transcriptional activity (Figure 3c). Since in the PR9 system PML/RARa protein localize mostly in the nucleus according to microscopy (Figure 3a) we investigated if there was a physical interaction between PML/RARa and NRF2 in both the cytoplasm and the nucleus. We performed a co-immunoprecipitation assay on fractioned nuclear and cytoplasmic extracts using an anti-NRF2 antibody and challenged the blot with anti-RARa antibody, demonstrating a physical interaction in both fractions (Figure 3d). In the experimental conditions there is a larger amount of complexed PML/RARa/NRF2 proteins in the nuclear fraction in line with the visual impression from the immunofluorescence analysis (Figure 3a). That probably indicates that PML/RARa inhibits NRF2 action by binding it to form a complex in the nucleus.

To investigate PML/RARa effect on NRF2 protein quantity we treated transfected Hek293T cells with PsG5-PML/RARa or control PsG5 constructs with $\mathrm{ZnSO}_{4}$. In PML/RARa-transfected cells, notwithstanding the oxidative stress, NRF2 expression abated by half in one hour; conversely, in the controls the expression increased by 1.6 times at the same time point $(p=0.001)$, and continued to increase up to 2.3 times at five hours while in PML/RARa-transfected cells it remained constant (Figure 3e).

NRF2 is a rapid turnover protein with a limited life span, so to see if PML/RARa affected the NRF2 life span we treated PR9 and Mock cells with $\mathrm{ZnSO}_{4}$, then with the protein biosynthesis inhibitor

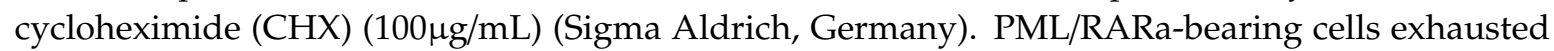
NRF2 allowance in less than two hours, whereas in control cells the stress due to the experimental condition preserved a considerable quantity of the protein (Figure 3f). Thus PML/RARa significantly reduced NRF2 protein, at least in part, by reducing its half life. A similar result was obtained treating the myeloid HL-60 cell line transfected with PsG5-PML/RARa or control PsG5 constructs with $\mathrm{ZnSO}_{4}$ for two hours and then with CHX $(100 \mu \mathrm{g} / \mathrm{mL})$ for four hours. In the control cells NRF2 expression was much higher respect to PML/RARa transfected cells, the difference persisted after CHX treatment (Figure 3g).

\subsection{PML/RARa Expression Sensitizes Cells to Ascorbate Treatment}

To evaluate NRF2 inhibition by PML/RARa on the oxidative stress defense mechanism of the cell we measured the levels of ROS content in NB4 and U937 cell lines and PR9 and Mock cell lines systems after induction with $\mathrm{ZnSO}_{4}$. As mentioned before zinc sulphate induces oxidative stress, and enhances NRF2 protein content, but in PR9 cells it induces PML/RARa expression as well. To further explore the oxidative unbalance, we respectively added 0.5 and $1 \mu \mathrm{M}$ of rotenone/antimycin $\mathrm{A}$ and $5 \mu \mathrm{M}$ Carbonyl cyanide p-(tri-fluromethoxy) phenyl-hydrazone (FCCP) and growing concentration of ASC (1.3 and $5 \mathrm{mM}$ ), to induce oxidative stress. In Mock cells zinc sulphate addition induced NRF2 expression and ROS cellular content remained stable, but PML/RARa expression in PR9 cells with consequent NRF2 loss of function caused significant augment of ROS (Figure 4a). Challenged with the other oxidants both cell line systems showed that NRF2 promptly responded to the challenge when PML/RARa is not present; conversely, its presence gravely impairs NRF2 homeostatic function (Figure 4a,b).

To confirm that NRF2 inhibition is involved in the mechanism of enhanced sensitivity to the ascorbate of APL cells we treated the two different cellular systems with ASC $1 \mathrm{mM}$ and measured NRF2 and HO-1 protein expression and found that the presence of PML/RARa downgraded NRF2 protein quantity and downregulated $\mathrm{HO}-1$ protein (Figure $4 \mathrm{c}, \mathrm{d}$ ). To make sure that the effect we saw was due to transcriptional deficiency of NRF2 we measured HMOX1 mRNA levels in the NB4/U937 system by RT-PCR after treatment with ASC $1 \mathrm{mM}$ for $24 \mathrm{~h}$. We observed a clear inhibition of HMOX1 transcript induction in NB4 cells as compared with control cells $(2.3 \pm 3.2 \mathrm{vs} .87 .3 \pm 8.2$ at $3 \mathrm{~h}$ and $2.9 \pm 2.9$ vs. $59.4 \pm 13.8$ at $6 \mathrm{~h}$ ) $p=0.005$ (Figure $4 \mathrm{e}$ ). To confirm our finding in a natural occurring system we then challenged with ASC $3 \mathrm{mM}$ for $24 \mathrm{~h}$ two sets of fresh primary blast, one from an APL patient and one from a patient with a different AML subtype, which confirmed that NRF2 downgraded in the presence of PML/RARa (Figure 4f). 
a-

b-
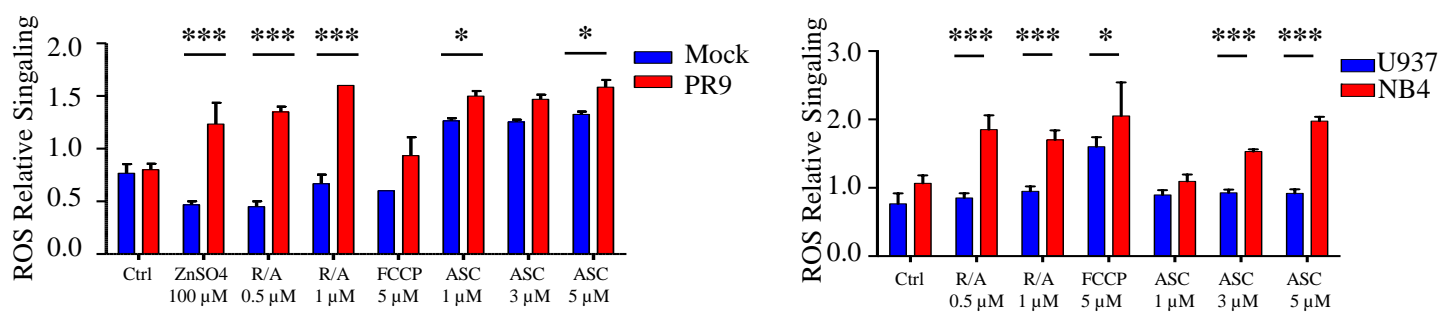

c-

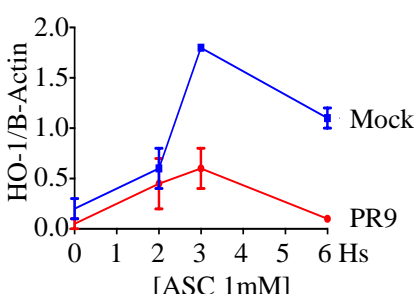

d-
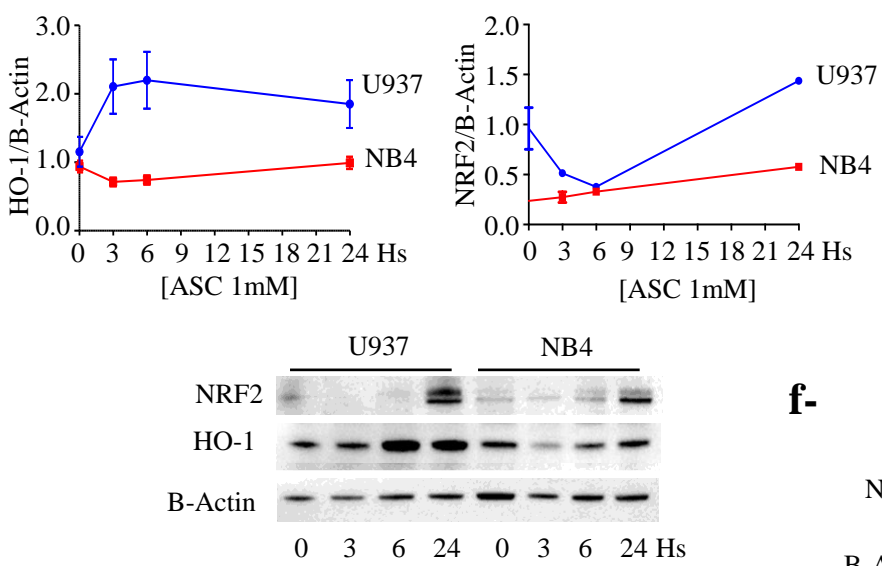

f-

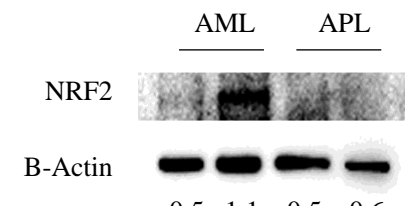

$\begin{array}{llll}0.5 & 1.1 & 0.5 & 0.6\end{array}$

Asc $3 \mathrm{mM}$

e-

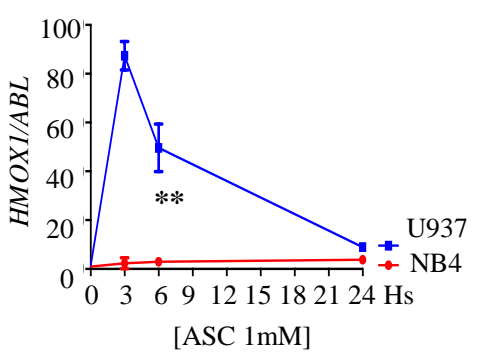

g-

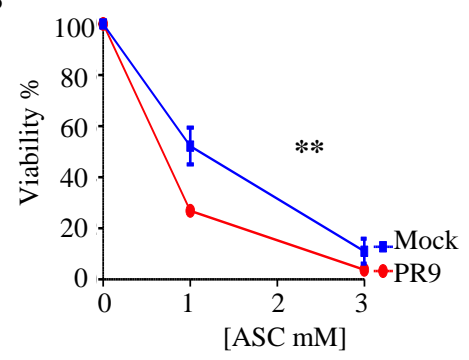

h-

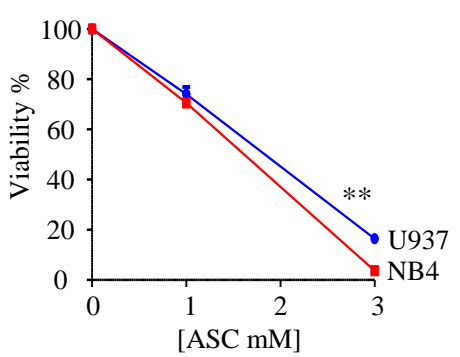

i-

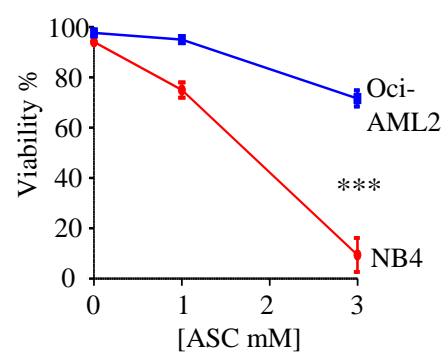

Figure 4. Promyelocytic leukemia / retinoic acid receptor $\alpha$ (PML/RARa) expression sensitizes cells to ascorbate treatment. (a) The levels of reactive oxygen species (ROS) content in PR9 and Mock cell lines systems were measured after induction of PML/RARa with ZnSO4. ROS levels were also evaluated after treatment with rotenone/antimycin A, Carbonyl cyanide 4-(trifluoromethoxy)phenylhydrazone (FCCP) and ASC as oxidants. In all systems the presence of PML/RARa induced a significantly higher level of ROS production. (b) The level of ROS production was evaluated in NB4, bearing PML/RARa, and U937 cells as control using ZnSO4, Rotenone/Antimicyn A, FCCP and ascorbate (ASC) as oxidant. 
NB4 cells produced higher level of ROS compared to U937 cells (c) PR9 and Mock cell lines systems were treated with ASC $1 \mathrm{mM}$ for six hours and NRF2 and HO-1 protein expression was evaluated by western blot. In PR9 cells the PML/RARa presence inhibited the expression of NRF2 and its target HO-1 protein. (d) NB4 and U937 cells were treated with $1 \mathrm{mM}$ ASC and evaluated for NRF2 and HO-1 production by western blot. In NB4 cells PML/RARa presence inhibited NRF2 protein and downregulated its target HO-1. (e) NB4 and U937 cells were treated with ASC $1 \mathrm{mM}$ for $24 \mathrm{~h}$ and HMOX1 mRNA expression was measured demonstrating NRF2 transcriptional deficiency. (f) Primary blasts from one AML and one APL patient were treated with ASC $3 \mathrm{mM}$ for $24 \mathrm{~h}$ : NRF2 was clearly abated in the APL blasts. (g) PR9 and Mock control cells were treated with ZnSO4 $100 \mu \mathrm{M}$ for two hours then with Asc at 1 and $3 \mathrm{mM}$ for $72 \mathrm{~h}$ and vitality was assessed by MTS assay. (h) NB4 and U937 cells were treated with increasing concentrations of ASC and viability was assessed using the ATP lite test. (i) NB4 and Oci-AML2 cells were treated with increasing concentrations of ASC and viability was assessed by cytometric analysis using Anexin - PI. *: $p<0.05,{ }^{* *}: p<0.01{ }^{* * *}: p<0.001$ by unpaired $t$-test. All the experiments were performed in triplicate.

We had proof that both in cell lines and fresh blasts from patients the presence of PML/RARa inhibits the expression of NRF2 target genes, which should sensitize cells to treatment with ASC $1 \mathrm{mM}$. In accordance with our data showing inhibition of NRF2 activity by PML/RARa, we observed; by ATP Lite test in NB4 cells and MTT viability test in induced PR9 cells, that PML/RARa sensitized to ASC, registering an enhancement of its efficacy in the presence of PML/RARa protein (respectively $p=0.04$ and 0.03) (Figure 4g,h).

\section{Discussion}

NRF2 unbalance leads to different but significant effects depending on the cell environment, its ability for suppressing carcinogenesis and preventing metabolic unbalance on one end but promoting cancer progression and resistance to chemotherapy on the other [41,42]. Stem cells have a low energetic profile with scarce ROS production and in the hematopoietic compartment loss of NRF2 results in defective differentiation and decreased survival as well as defective engraftment after hematopoietic stem cell (HSC) transplantation. It does not cause enhancement of ROS production as in most tissues but rather a sensitization to ROS hyper-production with increasing rates of spontaneous apoptosis and decreased survival when exposed to oxidative stress [33,43]. Consequently, NRF2 malfunction in APL-initiating stem cells is bound to expose them to redox unbalance in the presence of oxidizing agents.

Different cross-regulations link ROS production, NRF2 and the molecular mechanisms involved in APL: In physiological conditions both partners of the hybrid protein (PML and RARa) interfere with NRF2 regulation and function. In particular, nuclear and cytoplasmic PML acts as a stress sensor and minimizes ROS accumulation. In normal cells the loss of PML induces ROS production and NRF2 import to the nucleus, and increases NRF2 protein abundance and stability. PML directly facilitates ROS scavenging and, in unstressed cells, indirectly contains NRF2 accumulation and trans-activating capability both in the cytoplasm and in PML-NBs [28,44]. Retinoic acid receptor alpha (RARa) agonists, as all-trans retinoic acid (ATRA), impair induction of ARE-driven genes by NRF2 and RARa binds directly to NRF2 protein [45-47]. Studying the effect of treatment with megadoses of ascorbate in AML blast cells, we noticed as APL cells were particularly sensitive [17]. Here we describe that the impaired function of NRF2, the true orchestrator of redox balance and stress response, is at the base of that finding.

In the NB4 cell line ASC treatment, while reducing PML/RARa cellular content, causes APL phenotype reversion with the reassembly of PML-NBs, as observed by a confocal microscopy [17]. Following PML/RARa expression and PML NBs disruption in the PML/RARa-inducible cells PR9, NRF2 protein is clearly confined to the cytoplasm (Figure 3a). As demonstrated in several studies even if PML-RAR $\alpha$ is mainly nuclear as PML, it localizes in both nucleus and cytoplasm [48]. Lin et al. describes that the cPML/RAR $\alpha$ disrupts cPML-Smad2/3 interaction and antagonizes the tumor suppressive TGF- $\beta$ signaling, providing an additional mechanism for PML/RAR $\alpha$ oncogenic function [49]. Interestingly, 
cPML mutants interact with and stabilize the PML/RAR $\alpha$ cytoplasmic complex, resulting in potentiating of the PML/RAR $\alpha$ oncogenic function [50]. Another study by Giorgi et al. reported the enrichment of $\mathrm{cPML}$ at the endoplasmic reticulum (ER) and the mitochondria-associated membranes (MAMs) mediating apoptosis responses upon various stimuli [51]. By immunoprecipitation experiments we could see that PML/RARa interacts with NRF2 mainly in the nucleus, but we also see interaction outside the nucleus and we cannot exclude that PML/RARa could affect NRF2 function also by acting in the cytoplasm. The nuclear interaction may help in impairing NRF2 transcriptional activity by preventing its binding to the DNA responding elements. An inhibitory direct interaction between the Neh7 domain of NRF2 and receptors RARa and RXRa [45,47,52] has been described. PML/RARa could exert a similar action, since we demonstrate by CHiP analysis that in the presence of PML/RARa, NRF2 binding to the target ARE sequences is inhibited, but of course the same domain could act differently in the contest of the chimeric protein, and we did not investigate this. In APL primary cells, the basal NRF2 protein level is higher with respect to NBM, but its quantity and function is lower compared to other AML subtypes, affecting stem cells homeostasis and exposing tumor cells to redox unbalance.

Our data depict a new mechanism determined by the presence of PML/RARa in APL tumor cells involving NRF2. Contrary to a previous report on the short form of PML/RARa ectopically transfected in breast cancer MCF7 cells [47], our data show that in primary leukemic cells and in leukemic and non hematologic cell lines NRF2 action is hampered by PML/RARa: Its life span and transcriptional function are indeed highly reduced in the presence of PML/RARa, therefore its function in response to ROS accumulation results is insufficient (Figure 5).

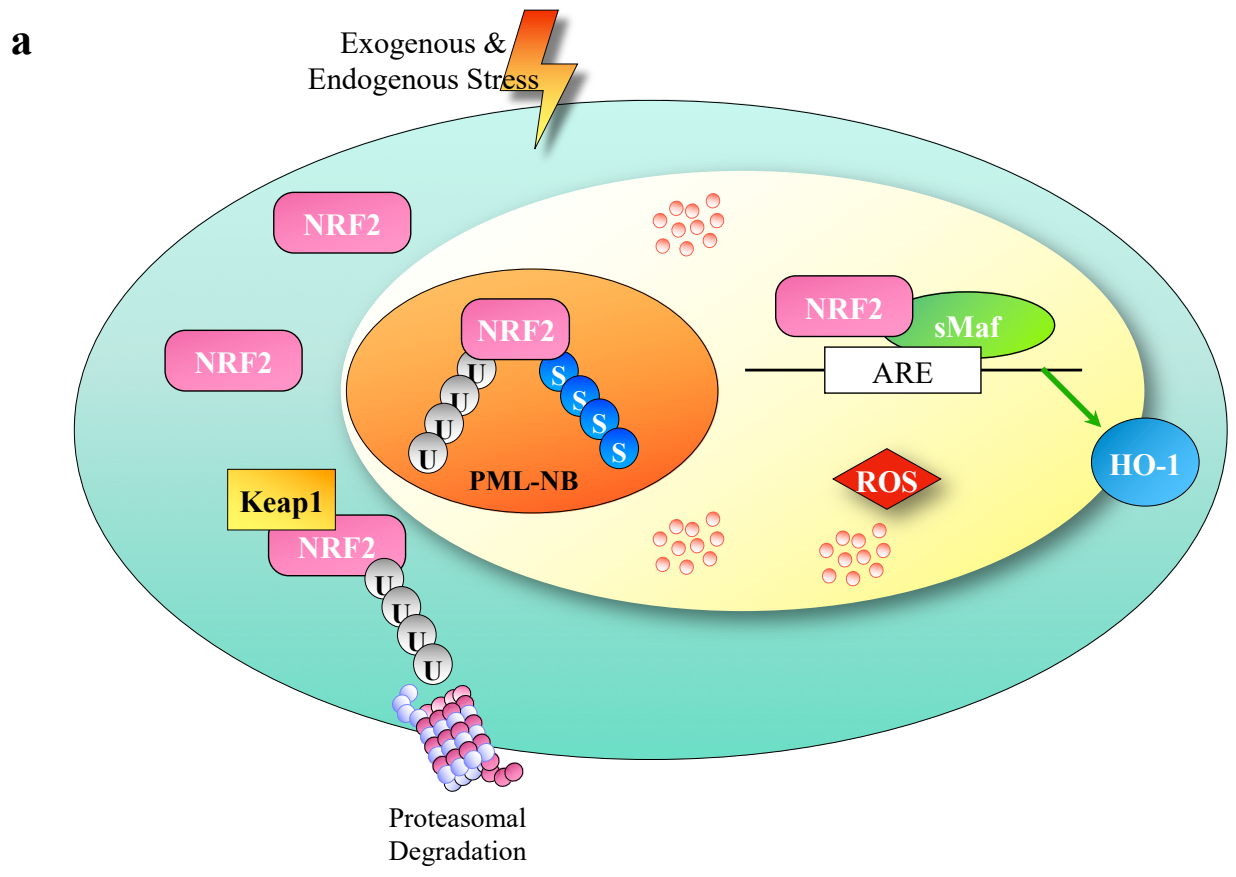

Figure 5. Cont. 


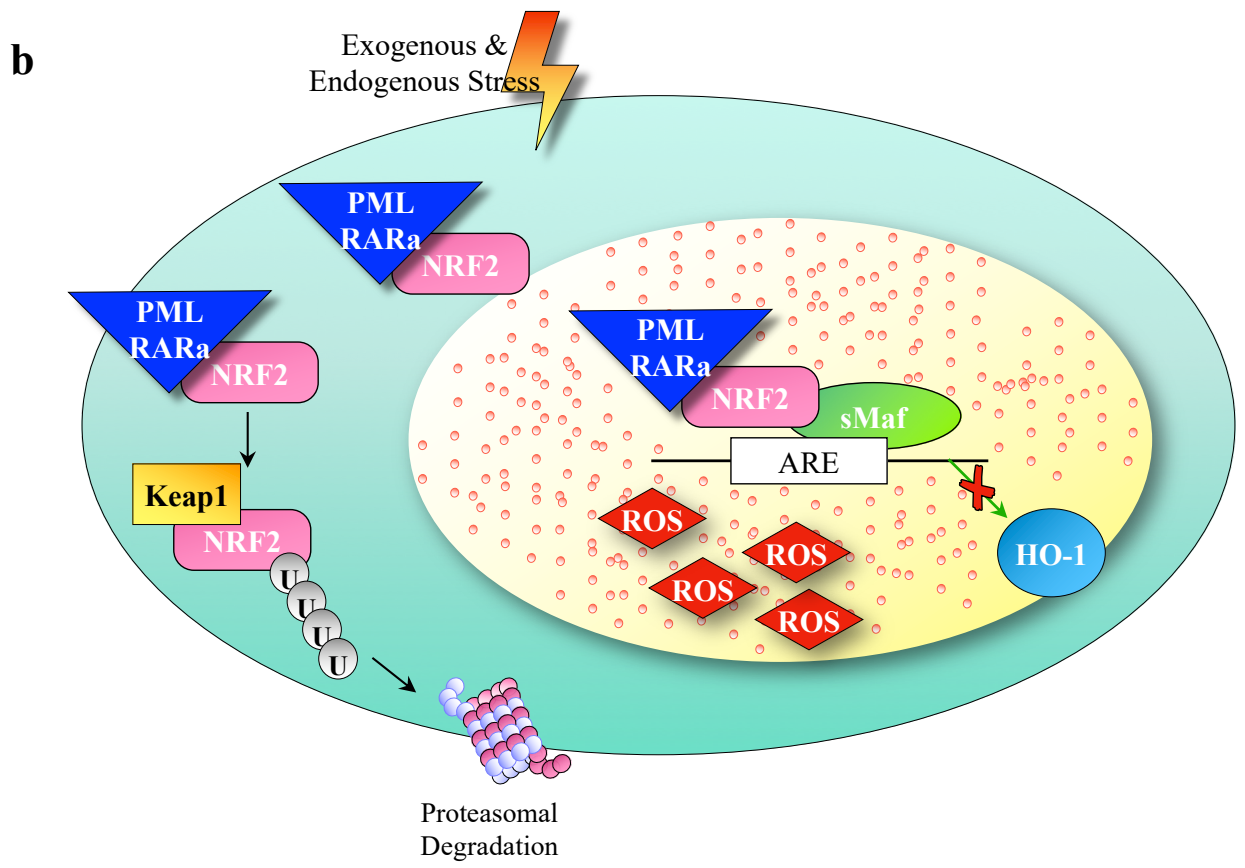

Figure 5. A model of NF-E2 p45-related factor 2 (NRF2) deregulation by Promyelocytic leukemia/retinoic acid receptor $\alpha$ (PML/RARa). (a) NRF2 activity is maintained at a low level via Keap1 binding, constitutive ubiquitination and proteosomal degradation. Electrophiles and oxidants inhibit its degradation, enabling NRF2 protein to accumulate in the nucleus initiating a genetic program to allow cellular adaptation to stress. (b) PML/RARa binds to NRF2 protein, segregates it to the cytoplasm, accelerates its degradation, and impedes its upregulation and induction of (antioxidant response elements) ARE-driven genes in response to electrophiles and oxidants; therefore, NRF2 function in response to ROS accumulation is insufficient.

\section{Conclusions}

Resistance to ATRA/ATO treatment is rare but grave. Treatment with high doses of ASC, directly targeting thePML/RARa protein and causing at the same time severe redox stress, is highly effective on APL cells and harmless on HSCs. Here we describe a novel direct regulatory effect of the fusion oncoprotein on the NRF2 transcription factor and cell metabolism in APL and propose high dose ascorbate treatment for APL patients who are resistant to therapy.

Supplementary Materials: The following are available online at http://www.mdpi.com/2072-6694/12/1/95/s1, Table S1: Anti-human antibodies used, Table S2: Primer List.

Author Contributions: C.B. co-wrote the manuscript carried out the experiments and analyzed the results; G.C. contributed data analysis and co-wrote the manuscript; S.T. performed W blot and Q-RT-PCR experiments; M.D. characterize and collect the samples from AML patients; S.M. and F.F. contributed with confocal experiments and critically reviewed the manuscript; G.G. carried out the cytofluorimetric analysis, F.L.-C. and M.T.V. critically reviewed the manuscript and amended the final report, N.I.N. contributed to study design, carried out and analyzed the experiments and co-wrote the manuscript. All authors have read and agreed to the published version of the manuscript.

Funding: This research was funded by AIRC 5x1000 call "Metastatic disease: the key unmet need in oncology" to MYNERVA project, \#21267 (MYeloid NEoplasms Research Venture Airc), by PRIN 2017WXR7ZT_004 and by AIRC IG 2018- ID 21406 project and Istituto Pasteur Italia- Fondazione Cenci Bolognetti-Call 2018. "The APC was funded by MYNERVA project, \#21267".

Acknowledgments: This work was supported by AIRC 5x1000 call "Metastatic disease: the key unmet need in oncology" to MYNERVA project, \#21267 (MYeloid NEoplasms Research Venture Airc). A detailed description of the MYNERVA project is available at http://www.progettoagimm.it, by PRIN 2017WXR7ZT_004 and by AIRC IG 2018- ID 21406 project and Istituto Pasteur Italia- Fondazione Cenci Bolognetti-Call 2018.

Conflicts of Interest: The authors declare no conflict of interest. 


\section{References}

1. Di Masi, A.; Cilli, D.; Berardinelli, F.; Talarico, A.; Pallavicini, I.; Pennisi, R.; Leone, S.; Antoccia, A.; Noguera, N.I.; Lo-Coco, F.; et al. PML nuclear body disruption impairs DNA double-strand break sensing and repair in APL. Cell Death Dis. 2016, 7, e2308. [CrossRef] [PubMed]

2. Wang, K.; Wang, P.; Shi, J.; Zhu, X.; He, M.; Jia, X.; Yang, X.; Qiu, F.; Jin, W.; Qian, M.; et al. PML/RAR $\alpha$ Targets Promoter Regions Containing PU.1 Consensus and RARE Half Sites in Acute Promyelocytic Leukemia. Cancer Cell 2010, 17, 186-197. [CrossRef] [PubMed]

3. Bernardi R1, P.P. Structure, Dynamics and Functions of Promyelocytic Leukemia Nuclear Bodies. Available online: https://www.mendeley.com/reference-management/web-importer/\#id_3 (accessed on 20 August 2019).

4. Grignani, F.; De Matteis, S.; Nervi, C.; Tomassoni, L.; Gelmetti, V.; Cioce, M.; Fanelli, M.; Ruthardt, M.; Ferrara, F.F.; Zamir, I.; et al. Fusion proteins of the retinoic acid receptor- $\alpha$ recruit histone deacetylase in promyelocytic leukaemia. Nature 1998, 391, 815-818. [CrossRef] [PubMed]

5. Boroughs, L.K.; Deberardinis, R.J.; Cell, N.; Author, B. Metabolic pathways promoting cancer cell survival and growth HHS Public Access Author manuscript. Nat. Cell Biol. 2015, 17, 351-359. [CrossRef]

6. Chartoumpekis, D.V.; Wakabayashi, N.; Kensler, T.W. Keap1/Nrf2 pathway in the frontiers of cancer and non-cancer cell metabolism. Biochem. Soc. Trans. 2015, 43, 639-644. [CrossRef]

7. Costa, A.; Scholer-Dahirel, A.; Mechta-Grigoriou, F. The role of reactive oxygen species and metabolism on cancer cells and their microenvironment. Semin. Cancer Biol. 2014, 25, 23-32. [CrossRef]

8. Hayes, J.D.; Dinkova-Kostova, A.T. The Nrf2 regulatory network provides an interface between redox and intermediary metabolism. Trends Biochem. Sci. 2014, 39, 199-218. [CrossRef]

9. Menegon, S.; Columbano, A.; Giordano, S. The Dual Roles of NRF2 in Cancer. Trends Mol. Med. 2016, 22, 578-593. [CrossRef]

10. Panieri, E.; Santoro, M.M. Ros homeostasis and metabolism: A dangerous liason in cancer cells. Cell Death Dis. 2016, 7, e2253-12. [CrossRef]

11. Wende, A.R.; Young, M.E.; Chatham, J.; Zhang, J.; Rajasekaran, N.S.; Darley-Usmar, V.M. Redox biology and the interface between bioenergetics, autophagy and circadian control of metabolism. Free Radic. Biol. Med. 2016, 100, 94-107. [CrossRef]

12. Cameron, E.; Campbell, A.; Jack, T. The orthomolecular treatment of cancer. III. Reticulum cell sarcoma: Double complete regression induced by high-dose ascorbic acid therapy. Chem. Biol. Interact. 1975, 11, 387-393. [CrossRef]

13. Cameron, E.; Pauling, L. Supplemental ascorbate in the supportive treatment of cancer: Prolongation of survival times in terminal human cancer. Proc. Natl. Acad. Sci. USA 1976, 73, 3685-3689. [CrossRef] [PubMed]

14. Yun, J.; Mullarky, E.; Lu, C.; Bosch, K.N.; Kavalier, A.; Rivera, K.; Roper, J.; Chio, I.I.C.; Giannopoulou, E.G.; Rago, C.; et al. Vitamin C selectively kills KRAS and BRAF mutant colorectal cancer cells by targeting GAPDH. Science 2015, 350, 1391-1397. [CrossRef] [PubMed]

15. Chen, Q.; Espey, M.G.; Krishna, M.C.; Mitchell, J.B.; Corpe, C.P.; Buettner, G.R.; Shaded, E.; Levine, M. Pharamacologic ascorbic acid concentrations selectively kill cancer cells: Action as a pro-drug to deliver hydrogen peroxide to tissuse. Proc. Natl. Acad. Sci. USA 2005, 102, 13604-13609. [CrossRef] [PubMed]

16. Chen, Q.; Espey, M.G.; Sun, A.Y.; Pooput, C.; Kirk, K.L.; Krishna, M.C.; Khosh, D.B.; Drisko, J.; Levine, M. Pharmacologic doses of ascorbate act as a prooxidant and decrease growth of aggressive tumor xenografts in mice. Proc. Natl. Acad. Sci. USA 2008, 105, 11105-11109. [CrossRef] [PubMed]

17. Noguera, N.I.; Pelosi, E.; Angelini, D.F.; Piredda, M.L.; Guerrera, G.; Piras, E.; Battistini, L.; Massai, L.; Berardi, A.; Catalano, G.; et al. High-dose ascorbate and arsenic trioxide selectively kill acute myeloid leukemia and acute promyelocytic leukemia blasts in vitro. Oncotarget 2017, 8, 32550. [CrossRef] [PubMed]

18. Mastrangelo, D.; Massai, L.; Lo Coco, F.; Noguera, N.I.; Borgia, L.; Fioritoni, G.; Berardi, A.; Iacone, A.; Muscettola, M.; Pelosi, E.; et al. Cytotoxic effects of high concentrations of sodium ascorbate on human myeloid cell lines. Ann. Hematol. 2015, 94, 1807-1816. [CrossRef]

19. Tahiliani, M.; Koh, K.P.; Shen, Y.; Pastor, W.A.; Bandukwala, H.; Brudno, Y.; Agarwal, S.; Iyer, L.M.; Liu, D.R.; Aravind, L.; et al. Conversion of 5-methylcytosine to 5-hydroxymethylcytosine in mammalian DNA by MLL partner TET1. Science 2009, 324, 930-935. [CrossRef] 
20. Tsukada, Y.I.; Fang, J.; Erdjument-Bromage, H.; Warren, M.E.; Borchers, C.H.; Tempst, P.; Zhang, Y. Histone demethylation by a family of JmjC domain-containing proteins. Nature 2006, 439, 811. [CrossRef]

21. Itoh, K.; Wakabayashi, N.; Katoh, Y.; Ishii, T.; Igarashi, K.; Engel, J.D.; Yamamoto, M. Keap1 represses nuclear activation of antioxidant responsive elements by Nrf2 through binding to the amino-terminal Neh2 domain. Genes Dev. 1999, 13, 76-86. [CrossRef]

22. Tao, S.; Liu, P.; Luo, G.; Vega, D.; Chen, H.; Wu, T.; Tillotson, J.; Chapman, E.; Zhang, D.D. p97 Negatively Regulates NRF2 by Extracting Ubiquitylated NRF2 from the KEAP1-CUL3 E3 Complex. Mol. Cell Biol. 2017, 37, 1-11. [CrossRef] [PubMed]

23. Zhang, D.D.; Hannink, M. Distinct Cysteine Residues in Keap1 Are Required for Keap1-Dependent Ubiquitination of Nrf2 and for Stabilization of Nrf2 by Chemopreventive Agents and Oxidative Stress. Mol. Cell. Biol. 2003, 23, 8137-8151. [CrossRef] [PubMed]

24. Dinkova-Kostova, A.T.; Kostov, R.V.; Canning, P. Keap1, the cysteine-based mammalian intracellular sensor for electrophiles and oxidants. Arch. Biochem. Biophys. 2017, 617, 84-93. [CrossRef] [PubMed]

25. Georgakopoulos, N.D.; Frison, M.; Alvarez, M.S.; Bertrand, H.; Wells, G.; Campanella, M. Reversible Keap1 inhibitors are preferential pharmacological tools to modulate cellular mitophagy. Sci. Rep. 2017, 7, 10303. [CrossRef]

26. Itoh, K.; Chiba, T.; Takahashi, S.; Ishii, T.; Igarashi, K.; Katoh, Y.; Oyake, T.; Hayashi, N.; Satoh, K.; Hatayama, I.; et al. An Nrf2/small Maf heterodimer mediates the induction of phase II detoxifying enzyme genes through antioxidant response elements. Biochem. Biophys. Res. Commun. 1997, 236, 313-322. [CrossRef]

27. Chowdhry, S.; Zhang, Y.; Mcmahon, M. Europe PMC Funders Group Nrf2 is controlled by two distinct $\beta$ -TrCP recognition motifs in its Neh6 domain, one of which can be modulated by GSK-3 activity. Oncogene 2014, 32, 3765-3781. [CrossRef]

28. Malloy, M.T.; McIntosh, D.J.; Walters, T.S.; Flores, A.; Goodwin, J.S.; Arinze, I.J. Trafficking of the transcription factor Nrf2 to promyelocytic leukemia-nuclear bodies: Implications for degradation of nrf2 in the nucleus. J. Biol. Chem. 2013, 288, 14569-14583. [CrossRef]

29. Hayes, J.D.; Chowdhry, S.; Dinkova-Kostova, A.T.; Sutherland, C. Dual regulation of transcription factor Nrf2 by Keap1 and by the combined actions of $\beta$-TrCP and GSK-3. Biochem. Soc. Trans. 2015, 43, 611-620. [CrossRef]

30. Hayes, J.D.; McMahon, M.; Chowdhry, S.; Dinkova-Kostova, A.T. Cancer Chemoprevention Mechanisms Mediated Through the Keap1-Nrf2 Pathway. Antioxid. Redox Signal. 2010, 13, 1713-1748. [CrossRef]

31. Koptyra, M.; Falinski, R.; Nowicki, M.O.; Stoklosa, T.; Majsterek, I.; Nieborowska-Skorska, M.; Blasiak, J.; Skorski, T. BCR/ABL kinase induces self-mutagenesis via reactive oxygen species to encode imatinib resistance. Blood 2006, 108, 319-327. [CrossRef]

32. Neumann, C.A.; Krause, D.S.; Carman, C.V.; Das, S.; Dubey, D.P.; Abraham, J.L.; Bronson, R.T.; Fujiwara, Y.; Orkin, S.H.; Van Etten, R.A. Essential role for the peroxiredoxin Prdx1 in erythrocyte antioxidant defence and tumour suppression. Nature 2003, 424, 561-565. [CrossRef]

33. Merchant, A.A.; Singh, A.; Matsui, W.; Biswal, S. The redox-sensitive transcription factor Nrf2 regulates murine hematopoietic stem cell survival independently of ROS levels. Blood 2011, 118, 6572-6579. [CrossRef] [PubMed]

34. Grignani, F.; Ferrucci, P.F.; Testa, U.; Talamo, G.; Fagioli, M.; Alcalay, M.; Mencarelli, A.; Grignani, F.; Peschle, C.; Nicoletti, I.; et al. The acute promyelocytic leukemia-specific PML-RAR $\alpha$ fusion protein inhibits differentiation and promotes survival of myeloid precursor cells. Cell 1993, 74, 423-431. [CrossRef]

35. Noguera, N.I.; Piredda, M.L.; Taulli, R.; Catalano, G.; Angelini, G.; Gaur, G.; Nervi, C.; Voso, M.T.; Lunardi, A.; Pandolfi, P.P.; et al. PML/RARa inhibits PTEN expression in hematopoietic cells by competing with PU.1 transcriptional activity. Oncotarget 2016, 7, 66386. [CrossRef] [PubMed]

36. Calvo, K.L.; Ronco, M.T.; Noguera, N.I.; García, F. Benznidazole modulates cell proliferation in acute leukemia cells. Immunopharmacol. Immunotoxicol. 2013, 35, 478-486. [CrossRef] [PubMed]

37. Reichard, J.F.; Motz, G.T.; Puga, A. Heme oxygenase-1 induction by NRF2 requires inactivation of the transcriptional repressor BACH1. Nucleic Acids Res. 2007, 35, 7074-7086. [CrossRef] [PubMed]

38. Kivelä, A.M.; Kansanen, E.; Jyrkkänen, H.-K.; Nurmi, T.; Ylä-Herttuala, S.; Levonen, A.-L. Enterolactone Induces Heme Oxygenase-1 Expression through Nuclear Factor-E2-Related Factor 2 Activation in Endothelial Cells. J. Nutr. 2008, 138, 1263-1268. [CrossRef] 
39. Piredda, M.L.; Gaur, G.; Catalano, G.; Divona, M.; Banella, C.; Travaglini, S.; Puzzangara, M.C.; Voso, M.T.; Lo-Coco, F.; Noguera, N.I. PML/RARA inhibits expression of HSP90 and its target AKT. Br. J. Haematol. 2019, 184, 937-948.

40. Appling, D.R. Software Review of Prism 5 Prism 5. GraphPad Software, Inc., 11452 El Camino Real, \#215, San Diego, CA 92130. www.graphpad.com. See Web site for pricing information. J. Am. Chem. Soc. 2008, 130, 18.

41. Sporn, M.B.; Liby, K.T. The good the bad and the importance of the context. Nat. Rev. Cancer 2013, $12,564$. [CrossRef]

42. Cloer, E.W.; Goldfarb, D.; Schrank, T.P.; Weissman, B.E.; Major, M.B. NRF2 Activation in Cancer: From DNA to Protein. Cancer Res. 2019, 79, 889-898. [CrossRef] [PubMed]

43. Owusu-Ansah, E.; Banerjee, U. Reactive oxygen species prime Drosophila haematopoietic progenitors for differentiation. Nature 2009, 461, 537. [CrossRef] [PubMed]

44. Sahin Umut, U.; Ferhi, O.; Jeanne, M.; Benhenda, S.; Berthier, C.; Jollivet, F.; Niwa-Kawakita, M.; Faklaris, O.; Setterblad, N.; de Thé, H.; et al. Oxidative stress-induced assembly of PML nuclear bodies controls sumoylation of partner proteins. J. Cell Biol. 2014, 204, 931-945. [CrossRef] [PubMed]

45. Xiu, J.W.; Hayes, J.D.; Henderson, C.J.; Wolf, C.R. Identification of retinoic acid as an inhibitor of transcription factor Nrf2 through activation of retinoic acid receptor alpha. Proc. Natl. Acad. Sci. USA 2007, 104, 19589-19594.

46. Chorley, B.N.; Campbell, M.R.; Wang, X.; Karaca, M.; Sambandan, D.; Bangura, F.; Xue, P.; Pi, J.; Kleeberger, S.R.; Bell, D.A. Identification of novel NRF2-regulated genes by ChiP-Seq: Influence on retinoid X receptor alpha. Nucleic Acids Res. 2012, 40, 7416-7429. [CrossRef]

47. Li, Y.; Wang, H.; Wang, X.J.; Tang, X. The short isoform of PML-RAR $\alpha$ activates the NRF2/HO-1 pathway through a direct interaction with NRF2. FEBS Lett. 2017, 591, 2859-2868. [CrossRef]

48. Kastner, P.; Perez, A.; Lutz, Y.; Rochette-Egly, C.; Gaub, M.P.; Durand, B.; Lanotte, M.; Berger, R.; Chambon, P. Structure, localization and transcriptional properties of two classes of retinoic acid receptor alpha fusion proteins in acute promyelocytic leukemia (APL): Structural similarities with a new family of oncoproteins. EMBO J. 1992, 11, 629-642. [CrossRef]

49. Lin, H.K.; Bergmann, S.; Pandolfi, P.P. Cytoplasmic PML function in TGF- $\beta$ signalling. Nature 2004, 431, 205. [CrossRef]

50. Bellodi, C.; Kindle, K.; Bernassola, F.; Dinsdale, D.; Cossarizza, A.; Melino, G.; Heery, D.; Salomoni, P. Cytoplasmic function of mutant promyelocytic leukemia (PML) and PML-retinoic acid receptor- $\alpha$. J. Biol. Chem. 2006, 281, 14465-14473. [CrossRef]

51. Giorgi, C.; Ito, K.; Lin, H.K.; Santangelo, C.; Wieckowski, M.R.; Lebiedzinska, M.; Bononi, A.; Bonora, M.; Duszynski, J.; Bernardi, R.; et al. PML regulates apoptosis at endoplasmic reticulum by modulating calcium release. Science 2010, 330, 1247-1251. [CrossRef]

52. Wang, H.; Liu, K.; Geng, M.; Gao, P.; Wu, X.; Hai, Y.; Li, Y.; Li, Y.; Luo, L.; Hayes, J.D.; et al. RXR $\alpha$ inhibits the NRF2-ARE signaling pathway through a direct interaction with the Neh7 domain of NRF2. Cancer Res. 2013, 73, 3097-3108. [CrossRef] [PubMed]

(C) 2019 by the authors. Licensee MDPI, Basel, Switzerland. This article is an open access article distributed under the terms and conditions of the Creative Commons Attribution (CC BY) license (http://creativecommons.org/licenses/by/4.0/). 